commemorated will be best preserved by giving extended space to these Des Moines talks about the beginnings of the state capital.

\title{
DES MOINES' FIRST HUNDRED YEARS
}

\section{By ORA WiLliams}

Iowa was beautiful and peaceful, a hundred years ago this month of May, and no part of it more beautiful nor peaceful than at this central spot where two fine rivers join for the long journey to the troubled oceans. All Iowa is the beautiful land, the chosen place, the ideal place for freedom, for life, for home. Never more delightful than when the prairies sparkle with the bright flowers of the springtime and the woodlands echo with the songs of the birds as they make their nests. Just a century ago a change was taking place. The leisure of a million years was about to be abruptly broken by an event ushering in a century of intense activity.

What did it mean that an American flag was to be unfurled here for the first time at the very center and heart of what was to become a commonwealth of unparallelled abundance?

Why disturb the quiet of the centuries with the clanking spurs of dragoons?

The stars and strips kissed the wild breezes and a new era commenced. We are celebrating that event this week-at least a few who are conscious of the meaning of the procession of the years and seek to understand the grand sequence of cosmic events. As measured by our fleeting lives, a hundred years is a long time, but a century is only a tick of the clock in the workshop of the Master Builder, a summer day on the calendar of eternity.

There was a reason. A new military post was to be established. It was to be Fort Des Moines No. 2. There has been a No. 1 and would be a greater No. 3. It was the familiar story-the flag, the sword, homes and industry.

There was little to break the silence on that May morning. There was the murmur of the rippling waters hardly held back by the frail dams of the beavers. Out upon the high levels the prairie chickens were calling their morning challenges, a timid herd was coming down to the salty deer licks, and perhaps there was the snort of a stray buffalo looking for its lost mate. There were trails leading over the hills, and the oaks were blazed by 
passing hunters, the bees were busy filling their tree homes with honey and there was sweet sap in the groves for the maple sugar.

It was a valley not only of beauty but of potential richness. Yet it was a wilderness. Not a white man's habitation within a hundred miles of the Raccoon forks. No red man had his lodge within two days' journey. Not an acre of virgin sod had ever been turned. No railroad locomotive west of the Alleghany mountains. No telegraph ticker anywhere.

A shrill whistle rang through the woodlands and was echoed from the hills. Notice was served then and there upon the sleeping wilderness that the time had come for the great awakening. The years of preparation had been tolled off and fulfillment was now to be. The willows bent to the wind and the tall grass waved a welcome.

A heavy laden little keel boat was brought, with much pulling and poling, and a little swearing, past rattlesnake bend and over the shallows below the junction of the two rivers, to the very point of land where the waters had been meeting for untold ages.

That was on May 20, 1843.

The scene was interesting, colorful, almost fantastic, one that would have been fine for the setting of a modern cinema. A tough and tanned army captain set his feet on the sandy beach. He had sharp eyes, wore a full beard, shining brass buttons, a heavy pistol, and his high boots were adorned with big spurs. He commanded an army-just one company of dragoons. The main body of the company had come overland a day or two before, riding an almost unmarked trail. Some of them had been brought to the place by another steamboat and were already at work. There were a few camp followers, and a cargo of equipment.

\section{DEPaRTURe ViEWED With Foreboding}

One there was who stood erect and tall and looked upon the unusual event with suspicion and inward protestation. $\mathrm{He}$ was an Indian chief arrayed in his most highly colored blanket and his best feathers. By his side was his wife, or rather several of them. He was helpless and sad.

It was not new ground for the captain. About a month before he had come in the steamer "Ione" to definitely locate the place for the new military post. He had set a stake and at that place his men set up a hickory pole and raised the flag as evidence that this was a part of the national domain.

The army captain was James Allen, a typical frontier soldier, familiar with the forests, the prairies, the Indians, the wild game. He had held important commands.

The Indian chief was Keokuk, the then recognized head of the confederated tribes, made so for his part in seeking to prevent 
, the Black Hawk war. He knew that his people had been deceived, abused, deprived of their best lands, but he was not only a good man in battle but a wise and diplomatic leader of his people.

There were not as many stars on that flag as on the one that flies near the same spot today. Some of the stars were a little dim from the threat of national dissolution. But it was to remain for three years as a reminder that this beautiful valley was dedicated to liberty and independence. Little did they know the full meaning of the ceremony in which they had a part. They were fixing the site for the capital of a future state. Their children were to help in adding to the stars of the blue field and to create a new race compounded of the best of many races, a culture into which would be woven all of man's twenty centuries of striving to go forward.

The flag raising was long overdue. Iowa was part of the better half of a continent that a strutting corporal had bartered away for a handful of coin. When Louisiana was carved up, that which is now Iowa was for a time tied up with Indiana and then Missouri, left for a few years a no-man's-land, later attached to Michigan, then Wisconsin, but was next on the roll call for promotion. The probationary period was short. Lawyers came all the way from St. Anthony's Falls to try their cases in Iowa. The pioneers were going through the motions of maintaining law and order, levying taxes, operating ferries, building plank roads, starting schools and colleges. Statesmen at the national capital were still debating whether the central and west part of Iowa was really worth taking from the Indians. But statehood could not longer be delayed. Men who plow with ox-teams and build cabins with broad-axes will not wait long for political trades and compromises.

\section{Civilization Is ON The WaY}

The taking over of the hunting grounds for a better use was done in shameful manner. It was inevitable but the hardship and suffering might have been avoided. A hundred years ago almost the only Indians remaining in Iowa were the Sacs and Foxes, in a strong federation of some forty groups or families. They were of Algonquin stock, had fought with the French against the English colonists, had been pushed into the west, and sided with the British against the young republic. They had agreed with the Sioux of the Dakotah stock, at Prairie du Chien, for a neutral line across northern Iowa, which had been broadened into a neutral strip.

That was not sufficient to stop all trouble; for an Indian in hot pursuit of the buffalo simply would not stop to read the "no trespass" signs. 
Gen. William Henry Harrison at St. Louis in 1804 secured an agreement to vacate all Indian lands east of the Mississippi river. That agreement was signed by Chief Pashepaha, principal chief of the confederation, then with what was known as the Missouri band of the Sacs. He afterwards admitted, as did Chief Keokuk and others, that this treaty was of doubtful validity, but they felt that it must be lived up to by the Indians.

Chief Black Hawk, the war chief of the Sacs, whose village below Rock Island was involved, never recognized the treaty as binding. When the little war he started was over and he was headed for imprisonment in Fortress Monroe, the Sacs and Foxes paid the price by relinquishing their land west of the river for fifty miles, except the reserve along the Iowa river. Later this "Keokuk Reserve" was bought and then followed the second "Black Hawk purchase" and the Des Moines valley became the home of the Indians left in Iowa.

Just before the time of the establishment of a new military post at the Raccoon forks, the Indian villages were scattered along the Des Moines river from Pittsburgh to Eddyville, and near the agency where the town of Agency City was afterwards located. Gen. Joseph M. Street had been sent there as agent, because he was a good friend of the Indians and because the northern fur traders wanted to get him away from Prairie du Chien and the Winnebagos. On his death he had been succeeded by Capt. John Beach, his son-in-law. Fairfield was nearest postoffice. To keep order, a company of dragoons under Capt. James Allen had been sent from Fort Crawford and occupied some old warehouses of the American Fur company on the river.

The Indians were satisfied and happy! ${ }^{2}$ The fur traders came up from St. Louis in steamboats and swapped beads and whisky for the valuable pelts of beavers and otters.

The Indians made summer excursions up the valley, to the Raccoon forks and far beyond. Every year they held a grand ceremonial visit on "Keokuk's Prairie" on which the WAAC of today get their training. An effort had been made to induce them to sell the lower part of the valley and move north, but they refused. They did not care to live any closer to the Sioux tribes.

About this time an incident occurred most unfortunate. On the occasion of one of the annual ceremonial visits at the summer camp near the Raccoon forks, a man came rushing into camp with a tale of horror, which resulted in formation of a posse of

\footnotetext{
1The Indians of today are loyal and harmonious. As Jonas Poweshiek and family were participating in the ceremonies at the monument marking the site of Fort Des Moines No. 2, one of the company of the WAAC from Fort Des Moines No. 3, greeted him as her cousin. She was Julia Kabance, of Oklahoma, and she has since been transferred to Tacoma. Other of the WAAC trained at Fort Des Moines were two Pawnees, two Penobscots, a Chippewa, a Delaware, a Sioux and a Winnebago.
} 
several hundred mounted braves led by Chief Pashepaho, who then was so old he had to be helped to his saddle. The trail was followed to Penoach, some twenty-five miles up the Raccoon valley, where the gruesome evidence was found of the truth of the story told.

A party of Delaware Indians had come over from the Missouri slope to visit their friends at the celebration. They had been followed by a large party of Sioux who caught them asleep and murdered all of them, some twenty-five in number. One alone, who was hiding in the tall grass, escaped and gave the alarm. The incident probably occurred right where the county seat of Dallas county now stands. The Sacs and Foxes were not too fond of fighting, but they were good warriors when aroused, and somewhere to the north a battle was fought in which most of the Sioux were treated as had been the Delawares.

\section{LAST GRAND CouncIl IN Iowa}

Time was ripe for a new job of bargaining. Iowa had been a territory more than four years. Major John Chambers was governor. Under directions from Washington he called the council at the agency. No more spectacular conference was ever held on Iowa soil. The governor, as representative of the Indian department, sat upon a dais beneath a great tent, arrayed in the uniform of a brigadier general, surrounded by a showy military staff. Capt. Allen was on guard with his dragoons. Antoine Le Claire was there to advise and interpret. Capt. Beach, himself a West.Pointer, acted as secretary. The traders with their account books were near by. There was the usual flow of oratory and meaningless flattery. One after another of the forty sub-chiefs spoke his piece. ${ }^{2}$

"We are happy to meet you here today," spoke Chief Keokuk as the talks came to a conclusion, "as the representatives of our Great Father in Washington, in friendly council."

The real estate put up at auction that day comprised all of the valleys of the Des Moines, Skunk, Raccoon, Grand, Boone and other rivers-a rich domain. There was little chance for driving a hard bargain. The Indians would give up their Iowa home and go away. The "Great Father" would pay their debts to the traders and give them a tribal annuity in some home "south of the Missouri." The claims of the traders footed up $\$ 258,566.34$. Chief Keokuk was in no mood to argue about their accuracy. Three

2This important treaty, negotiated on Oct. 11, 1842, at Agency, by which the Des Moines valley was opened for settlement by white men, was signed on behalf of the Sacs by Keokuk, Keokuk Jr., Appanoose, Pashepaho, Ionah and others; and on behalf of the Foxes by Poweshiek, Puchakowa, Kishekekosh, and others, forty-four in all. On behalf of the United States it was signed by Governor Chambers, and Beach, LeClaire, Smart, Allen, Ruff and Alfred Hebard. 
firms got in nearly all, namely: Pierre Choteau, Jr. \& Co., St. Louis, $\$ 112,109.47$; W. G. and G. W. Ewing, of Indiana, $\$ 66,371.83$; J. P. Eddy \& Co., "of Ioway" \$52,332.78.

Out of the tribal annuity of $\$ 40,000$ a year, the sum of $\$ 30,000$ was to be expended by the Indian bureau for "charitable purposes." The principal chiefs, some forty of them, were to receive $\$ 500$ each. The body of Chief Wapello, who had recently died, was to be placed by the side of "their late friend and agent, Gen. Joseph M. Street," and this little burying place by the side of the Burlington railroad at Agency is a continuing testimonial to the fact that a good agent and a good chief may become warm friends.

All the Indians were to move soon to lands west of the Red Rock line and at a time to be fixed by the Indian bureau they would go to Kansas. There had been five or six thousand of these Indians at one time, but war and hardship had reduced the number, and it is said that only about 2,200 followed Allen and Beach and the traders to the Raccoon forks. Many went at once to Kansas, others followed in a year or two, and after three years only about 200 were living on the "Keokuk Prairie," or as some called it the "Agency Prairie."

Uncle Sam had already commenced to give the land away in big farms. It had come easy. Napoleon had disposed of his shady title to all of the Mississippi valley for about four cents an acre; Keokuk, who had a better title, raised the price for the portion he claimed and got about twelve cents an acre.

The Agency treaty was signed Oct. 11, 1842.

All this was background for the ceremony of flag raising at Raccoon forks. Orders were given in February for locating the post. Allen had been scouting along the valley and knew the precise spot where it should be placed. Col. Stephen W. Kearny had looked it over when he returned from the Sioux country and reported upon it. Col. George Croghan had been sent out from Washington to see about the situation and he said the Raccoon forks was a good place, but like most army officers, he sought to discourage more frontier posts.

"There is altogether too much traveling between the several forts for the quiet of the frontier," he reported, "and good roads will only increase the evil by opening the whole territory to the ravenous appetites of lawless vagabonds and more greedy land speculators."

It was as good an argument as any in opposition to military posts and roads between them, but it did not prevail.

\section{Fort Des MoInes Surroundings}

It was on May 10, 1843 that Allen reported he had actually located the post. He had induced Major Sanford, of the American 
Fur company to bring him and some of his men to the Raccoon forks on the fur trading steamboat "Ione" but the pilot would not risk a second trip. When Allen ${ }^{3}$ arrived on the 20th some of the company of fifty dragoons had come ahead, across country; and the next day they were joined at "the forks" by Capt. J. R. B. Gardinier, with a company of infantry, formerly stationed at Fort Crawford, and the "army" was thus raised to about one hundred men including the officers. Allen had asked the quartermaster to provide him with "ten mechanics and five laborers and four yoke of oxen, and tools and implements," but every frontier soldier knew how to wield an axe as well as aim a gun. The story of the construction of the military post buildings is fairly well known.

A town grew up quickly around the post. The Ewings opened a new trading place. The Scotts opened up a farm on the east side of the river. They were from Sangamon county, Illinois, where one of the Scotts was a colleague of Lincoln in the legislature at Vandalia. It was almost useless for Allen to try to hold back the flood of "lawless vagabonds" and others. Many were the squatters upon the land in the beautiful valleys.

Captain Beach, Indian agent, set up for business not far from the post. Chief Keokuk camped on ground familiar to him on the fine prairie that stretches down to Avon and the junction of the North river. It was tradition, at least until a comparatively recent time, that the big elm tree that today stands in the highway, close to the pavement, on the hill south of the electric power plant, was known as "Keokuk's Lookout." If you should climb that tree today you might see all over the City of Des Moines. Chief Keokuk sent his watchers up that tree to keep an eye open for trouble.

\section{Farewell to Des MoINes Valley}

The dragoons were not idle. There was trouble over farming and trading rights. Roads had to be built. There were feuds between ferrymen. Soon the stage coaches were rumbling past Fort Des Moines carrying fortune seekers to California and Oregon or Pike's Peak. The peace of the valley was never to return.

When final orders came from Washington that all Indians

\footnotetext{
${ }^{3}$ Capt. Allen, in a letter dated Dec. 20, 1842, reported to the War Department that he had gone up the river as far as the Raccoon forks and selected the site for a military post; orders were issued from Jefferson Barracks February 20, 1843 to proceed with the establishment of the post and erection of buildings; Captain Allen proceeded starting April 29 with a small detachment of dragoons: on May 10 he wrote stating that the post had been located. Company I, First U. S. dragoons, went overland to the post and Captain Allen, with some of the officers and others, arrived May 20, 1843.

¿Capt. Gardinier's company was F, of the First Infantry, and consisted of fortyfour men, who had been at Fort Crawford. The force at Fort Des Moines was therefore both mounted and unmounted infantry to the number of about 100 men and of ficers.
} 
must be out of Iowa by October 11, 1845, Capt. Allen protested that it ought not to be done, since many of those left were infirm or ill and would not fare well in winter time in a new reservation. The War department refused the request for delay, but delay was necessary, and not until in March, 1846, did the last of them go. In the meantime Captain Allen had started at the head of the Mormon Battalion for California to assist his old friend, Kearny, in holding the west coast, and he died on the way. It was Lieut. Grier who had the unwelcome task of compelling the last of the Indians to depart. Small bands had hid away and hoped to be overlooked.

Chief Poweshiek, of the Fox tribe, had his camp near Fort Des Moines not in close contact with Chief Keokuk and his Sacs, but where the City of Des Moines is now. He had gone on to Kansas in quiet submission to orders but some of the Foxes remained in southern Iowa and never left.

In the Polk county court house is a mural painting by Prof. Chas. A. Cumming showing some of the Sacs gathered in a small group around Chief Keokuk and his family, taking a last look at the beautiful valley they were soon to leave. They stood on "Van's Hill" overlooking the fort soon to be abandoned-protesting, wailing, resisting, lamenting. It was the saddest day in Indian history for Iowa.

This was their last stand in Iowa. Fate had overtaken them and they bowed to the power of civilization. The Foxes, then the lesser tribe of the confederation, looked longingly from their home in the south which they called the "Lonesome Place" to their Iowa hunting grounds, and in due time they sent a committee of head men to arrange for return; and this committee bought eighty acres of land along the lowa river, in Tama county," paying $\$ 1,000$ therefor, which farm was finally expanded into the present 3,600 acres owned by about 300 Foxes, or Mesquakies, as they prefer to be called. The smaller bands that never left Iowa also joined their brothers on the Iowa river.

For many years these returned exiles refused to accept the white man's ways, but today they are good Americans and have thirty-three of their young braves in uniforms fighting for the country that was truly theirs.

The steamboats were the chief agencies of transportation until the railroads came twenty years later. Iowa was settled and

\footnotetext{
"The Mesquakies living in Iowa are the Mississippi band of the Fox Indians. Small groups trickled back to their old homes and on July 10, 1857, Chief Matauoqua and four others bought eighty acres of land in Tama county for $\$ 1,000$ of tribal money. The title was placed in the hands of the Governor of lowa in trust for the Indians, Iater transferred to Secretary of the Interior. The Commissioner of Indian affairs stated in $\mathbf{1 8 9 6}$ that at that time there were $\mathbf{5 1 1}$ Sacs and Foxes in Oklahoma and 398 in Iowa, while eighty-one of the Missouri family of Sacs and Foxes were living in Kansas and Nebraska. The Indian land in Tama county in 1943 aggregated 3600 acres.
} 
organized by people who came down the Ohio and up the Mississippi. A dozen or more steamboats shuttled between St. Louis, then the great western trade center, and Des Moines. They had funny names and big whistles. There was the Ione and the Agatha, the first to come. Then there was the Des Moines Belle, the Leviathin, the Time and Tide, and the Movestar, not "Moviestar." The big side wheeler, Flora Temple tied up at the foot of Court avenue and there was merriment at the little town. One steamboat ventured up to Fort Dodge, possibly more than one. Big dams were planned for the lower river.

Neither the army captains nor the steamboat captains were first in the Des Moines valley. Jean Faribault was a factory for the Choteau firm before the century was very old. An old map shows a cattle trail across Iowa from St. Louis to Pembina made dusty as early as 1820 and it followed up the Des Moines and Raccoon valleys. Stephen W. Kearny saw a herd of 5,000 buffalo near the head of the Raccoon river. Albert M. Lea accompanied him to the St. Peters and made the first map on which the name Iowa appeared. Marquette and Joliet saw the . Des Moines river just 270 years ago. They found moccasin tracks in the sand near the head of the rapids of the Mississippi and followed them to the "Mou in gue e na" river where they smoked with friendly Indians.

\section{GOOD SOLDIERS ON THE FrONTIER}

The military men who crossed the big river in the vanguard of advancing civilization were real soldiers. Capt. James Allen was a West Point man, and with his friend Col. Stephen W. Kearny, and probably Capt. Nathan Boone, son of the famous Daniel, had helped to transform some of the frontier infantry regiments into mounted dragoons. His company I, First U. S. Dragoons was know as "Allen's Dragoons." Capt. J. R. B. Gardinier, who brought the infantry company to Fort Des Moines was a cadet in the class with Jefferson Davis and later became prominent in the Mexican war. The quartermaster at Fort Des Moines, Lieut. C. F. Ruff, was also a West Point man, and so was Lieut. Joseph H. Potter, Lieut. Robert S. Granger and Lieut. Patrick Noble, all of them at Fort Des Moines. The adjutant of the post, Lieut. John $H$. King must have been a superior man for he rose to the rank of major general later.

When Captain Allen took general command of Fort Des Moines he turned his dragoon company over to Lieut. Wm. N. Grier, who graduated from West Point in 1831 and served forty years in the army. He it was who had the job of leading the last of the Indians out of Iowa and into Kansas. 
It was Gen. Winfield Scott who was at the head of the army when Captain Allen hesitated about having a second Fort Des Moines and General Scott insisted upon the name finally accepted. ${ }^{\circ}$ Both Kearny and Allen had been at the first Fort Des Moines which was maintained from 1834 to 1837. Gen. Lewis Cass was governor of Michigan when Iowa was a part of that state and he presided at the treaty of 1825 at Prairie du Chien.

Gen. Zachary Taylor was commandant at Fort Crawford, when Chief Black Hawk was brought there in chains by Lieut. Jefferson Davis, and it was Gen. Joseph M. Street, the kindly Indian agent, who protested that a fallen foe should not thus be treated. They used to show you, in Prairie du Chien, the window out of which General Taylor's daughter climbed one moonlight night to elope with Jefferson Davis. But Davis was not the only man who served in the army in Iowa who deserted the stars and stripes; for Gen. Henry Atkinson had serving with him at the post in the neutral strip, Simon B. Buckner, Henry Heth, Abraham Buford and A. W. Reynolds, all of whom took part in the secession movement.

John C. Fremont, then a lieutenant of engineers, knew the Des Moines valley. He explored it and wrote a fine account of the birds and flowers. You will recall that when old Senator Benton of Missouri discovered that his daughter Jessie was about to fall in love with the young engineer, the senator had him "exiled" to be an inspector of dams along the Des Moines river. Jessie Benton ran away and visited her young man on the dam at Bentonsport.

Robert E. Lee was engaged in engineering at the Des Moines rapids, U. S. Grant bought hogs and hides for his father in Iowa, Francis Scott Key was an attorney in litigation over the half breed tract. John Brown drove a yoke of oxen along Grand avenue in Des Moines and chatted with friends on his way to Osawatomie.

It was no accident that Iowa became the first free state carved out of Louisiana. The pioneers who crossed the old Northwest Territory brought their bibles and spelling books as well as their axes and spinning wheels and rapidly enlarged the area where free labor and untrammeled genius could work out all problems. The fight for free soil culminated in Iowa. The one big political issue of the day was that of slavery. Everything had been subordinated to that for a quarter century. But the time of compromises was nearing a close.

Slavery was very near to Iowa. Much of the early immigration that followed the Mississippi river up from the south was tinged

"The official designation was by Lewis Cass, then Secretary of War under President Jackson. The order read: "Let the post be called Fort Des Moines, and let it be a double ration post." 
with slavery sentiment. Nearly all the army officers had slave servants. Dr. Emerson, who owned Dred Scott, lived for some time in Iowa. Colonel Kearny had a slave to care for his horses at old Fort Des Moines. Joseph Smart, blacksmith and interpreter, had a slave at Agency whom he sold to a Missouri planter. The Sac and Fox Indians held tribal slaves. A Kentucky lawyer (M. D. McHenry) brought his twenty-six slaves to Des Moines, freed them here, and some of them remained for long in his service.

Iowa's first territorial governor was a friend and fellow officer close to Gen. Andrew Jackson. The second was an officer under Gen. William Henry Harrison. Martin Van Buren signed the bill for Iowa territory, and James K. Polk signed the bill for statehood. John Tyler was president when Fort Des Moines No. 2 was established.

The political pendulum swung violently in those days. States were admitted in pairs-a slave state and a free state. Iowa didn't get a chance until the compromisers coupled it up with Florida in one congressional act. Between the frontiersmen with their long rifles and the school masters with their quotations from Washington and Jefferson and Webster and Clay, there was rivalry. The voice of Stephen A. Douglas was the last heard in Iowa pleading for time for the slave owner. Abraham Lincoln stood on an Iowa hill and looked toward the Pacific with prophetic eyes; and he used his "military scrip" by which he was paid for his part in the Black Hawk war to acquire two Iowa farms, ${ }^{7}$ the only tillable land he ever owned.

Statehood came to Iowa the very year that the Sacs and Foxes were led away. When the flood gates were opened, the vast reservoir of American enterprise and ambition poured out its great wealth into the valley that the Indians said was good and beautiful.

\section{The Third Fort Des MoInes}

More than half a century was to pass before the third Fort Des Moines was to be even in contemplation. The village of a few dozen families had become a city of 65,000 , the capital of a great state, the cross-road of a vast and growing commerce. That city had a quick-witted and aggressive representative in Congress who had been a soldier in the Civil war, Capt. John A. T. Hull. He had risen to the position of head of the military committee and of commanding influence. In the year 1900, at his instance, there was

\footnotetext{
'Lincoln's two farms were one of forty acres in Tama county and one of one hundred twenty acres in Crawford county. He did not retain the Tama county land, but the Crawford county farm remained in his estate until sold by Robert T. Lincoln in 1892.-E. R. Harlan, in ANNALS OF IOWA, Vol. XV, p. 621 .
} 
passed an act authorizing a new military post at the capital of Iowa, the reason stated for same being as follows:

"The Indians have ceased to be a disturbing element in the settlement of territories, thus permitting the abandonment of many small posts that until recently were scattered along the frontier, to concentrate their troops thus released near the centers of population."

There was criticism and doubt, especially in political circles, but Des Moines cooperated in securing a suitable site at a point some four miles south from the Raccoon forks. Land was given and later a site was secured for a rifle range; splendid buildings were built; a thoroughly modern military post was created where there had been farm land and pastures.

This was made to be a cavalry post and was long maintained as such. The formal dedication was on November 11, 1903. By the shifting necessities of the reduced military establishment, the post became a training center, then a basic hospital for the army.

When Congress authorized the Women's Army Auxiliary Corps on May 14, 1942, Fort Des Moines No. 3 seemed to be ready made and waiting for this daring innovation in military personnel, and on July 20, 1942 the First WAAC training center was opened here. The plans called for a normal capacity of from 7,000 to 8,000, and the enlargement of the post followed of necessity. From the day of the opening until now, a steady stream of patriotic young women has been going through Fort Des Moines No. 3, and while other training centers have been opened, this remains the one school for officers in this branch of the service.

It would not be worth our while to call to mind the primitive scene of a hundred years ago when Fort Des Moines was established in a wildermess at the site of the present great state capital with 170,000 inhabitants, nor to mark the steps of our century of wonderful progress, but that we might thereby gain inspiration for the journey of the coming years and more firmly seize upon the traditions upon which our State is built. Our Iowa state makers solved the problems of their times. They shaped the pattern of our social and political structure. Our generation, and others to come, will do well to ponder the lessons of the past.

\section{Iowa Is Fulfilling Destiny}

What happened here a century ago was on the grand agenda of the Master Craftsman of the universe. The pioneers knew this as they cracked their bull-whips over the horns of the leaders. The disheartened red men had no words for it but they understood. The possibilities and the destiny of this virgin garden were foreseen by keen observers. 
One such student of life came this way and painted the portraits of the Indian chiefs in Iowa. The portrait of Chief Keokuk, mounted and richly adorned, is a prized possession of the historical collection temporarily under my care. It was by George Catlin, not only a portrait painter but one with eyes to see realities. $\mathrm{He}$ wrote that Iowa was "like a garden waiting only cultivation," and that "it is here where the true character of the American is to be formed." Here would be developed that which would be a "lofty principle that strikes between meanness and prodigality, between literal democracy and autocracy, between low cunning and self engendered ingenuousness." In fairly grand exultation he exclaimed:

"It is to be the mint of the country."

The famous Iowa band of missionaries came along charging themselves with showing these hardy trail-blazers the route to heaven; but Dr. Asa Turner was disturbed at the prospect because, as he said, he had found "the region so beautiful there might be an unwillingness to exchange it for the paradise above."

The famous philosopher who traveled much and saw everything, Alexis De Tocqueville, peered over the rim into this midland region of America and set it down:

"The most magnificent dwelling place prepared by God for the abode of man."

He could hardly have said more had he seen Iowa a hundired years after the initial steps were taken in that month of May, 1843, of taking the best of it over for this most magnificent dwelling place.

Poets also caught glimpses of this near-paradise. William Cullen Bryant might well have had the Des Moines valley in his mind's eye when he wrote:

"These are the gardens of the desert, these The unshorn fields, boundless and beautiful, For which the speech of England has no nameThe Prairies. I behold them for the first time And my heart swells while the dilated sight Takes in the encircling vastness."

In due time the McGuffey one-room schools had prepared the way for something higher than the lyceum and spelling-school, and the lecturers and revivalists came; and when one of the best, Theodore Tilton, was twitted about his praise of the West he made reply:

"I am sometimes told by friendly critics that I draw my western pictures in over-colors. No, I endeavor always to under-estimate rather than over-state my admiration for the West.

"It is a majestic region. Its people belong to the nobility of mankind. Its prospective growth is beyond calculation.

"Its soul is on fire. 
"Its ambition is to rule the land. Its opportunity is not far in the future. Its triumph, when it comes, will be complete. The West is to be the dictator of the Republic."

This is what Chief Keokuk was yielding to the might of the advancing civilization. This is what Captain Allen was taking over as he raised the little American flag at the Raccoon forks of the Des Moines. Truly the soul of the west was on fire, and that fire has never been quenched.

Another day has been marked off on the calendar of eternity; many more stars have been added to the blue field of the flag of the free; there will never again be a leisurely million years for this region; the pattern has been set for man's abode in this magnificent dwelling place.

It is the immediate task and high duty of our generation, of all of us who have so richly inherited from the courage and the genius of the pioneers, to see to it that in this "mint of the country," it can always be said that "its soul is on fire."

For a full century, the City of Des Moines, capital of an empire of overflowing abundance, has fulfilled its assigned part in this noble adventure.

\section{FORT DES MOINES AND DES MOINES ${ }^{\varsigma}$}

\section{By VernoN R. SEEBURGer}

Des Moines is one hundred years old today. It was founded by the United States Army under the leadership of Capt. James Allen, who, with fifty-two dragoons, landed at the Raccoon forks on the afternoon of May 20, 1843. Because of the rather unusual reasons for locating a fort at this place and at that particular time, pass for the moment a description of the fort, the topography at that place as it existed then, and go back into some of our earlier American history because it dovetails into the actual establishment of the fort here.

Following the War of 1812 a tremendous surge of emigration took place from the Atlantic seaboard over the Allegheny mountains into the so-called northwestern territories, or the Northwest Territory. That area comprised the present states of Ohio, Michigan, Wisconsin, Indiana and Illinois. You will recall from the reading of history that the Indian tribes in that area allied themselves with

\footnotetext{
${ }^{8}$ Address delivered by Vernon R. Seeburger, president of Des Moines Pioneer club, at the Des Moines Centennial program in the Des Moines city council chamber May 20, 1943 and before several city clubs.
} 
Copyright of Annals of Iowa is the property of State of Iowa, by \& through the State Historical Society of Iowa and its content may not be copied or emailed to multiple sites or posted to a listserv without the copyright holder's express written permission. However, users may print, download, or email articles for individual use. 